\title{
Erratum to: Potential of the system of rice intensification for systemic improvement in rice production and water use: the case of Andhra Pradesh, India
}

\author{
Ravindra Adusumilli $\cdot$ S. Bhagya Laxmi
}

Published online: 8 February 2011

(c) The Author(s) 2011. This article is published with open access at Springerlink.com

\section{Erratum to: Paddy Water Environ}

DOI 10.1007/s10333-010-0230-6

For two data points in Table 3 of the article conversion of the numbers from quintals per ha to tons per ha was not done. In the second and third rows of the third column of Table 3 , $8.38 \mathrm{tha}^{-1}$ should be $0.83 \mathrm{tha}^{-1}$, and the $-5.45 \mathrm{t} \mathrm{ha}^{-1}$ should be $-0.55 \mathrm{t} \mathrm{ha}^{-1}$. The mistake is regretted.
Published online 24 October, 2010 in Paddy Water and Environment.

Open Access This article is distributed under the terms of the Creative Commons Attribution Noncommercial License which permits any noncommercial use, distribution, and reproduction in any medium, provided the original author(s) and source are credited.

The online version of the original article can be found under doi:10.1007/s10333-010-0230-6.

R. Adusumilli $(\bowtie) \cdot$ S. Bhagya Laxmi

Watershed Support Services and Activities Network

(WASSAN), Hyderabad, India

e-mail: raviwn@gmail.com

S. Bhagya Laxmi

e-mail: bhagyawn@gmail.com

R. Adusumilli

Development Economics Group, Wageningen University,

Wageningen, Netherlands 